\title{
Mídia Educação e a formação cidadã: análise das oficinas de rádio da escola municipal Olavo Soares Barros de Cambé - PR
}

\author{
Luzia M. Yamashita Deliberador* \\ Mariana Ferreira Lopes**
}

\section{Resumo}

O presente artigo trata de um estudo sobre mídia educação baseado nas oficinas de rádio ministradas para alunos da $4 \underline{a}$ série (quinto ano) do ensino fundamental da Escola Municipal Olavo Soares Barros, em Cambé - PR. O trabalho apresenta por objetivo refletir teoricamente sobre a mídia educação e avaliar a possibilidade de sua prática incitar o comprometimento dos jovens com a sua realidade e, assim, servir de alicerce para a construção de sua cidadania. A metodologia utilizada consistiu em pesquisa bibliográfica sobre os pressupostos da mídia educação e também na pesquisa-ação que compreendeu as oficinas realizadas no período de agosto a dezembro de 2008. Conclui-se que quando a mídia educação é trabalhada em seu contexto produtivo buscando despertar as crianças a refletirem sobre as questões relativas ao seu entorno social, seja ele a sua escola, seu bairro ou sua cidade, estabelece-se a uma educação para a cidadania, configurada pela formação participativa e de comprometimento dos envolvidos.

Palavras-chave: Mídia educação. Cidadania. Comprometimento.

\section{Media education and training citizen: an analysis of radio workshops of the municipal school Olavo Soares Barros de Cambé - PR}

\section{Abstract}

This article deals with a study on media education workshops based on the radio given to students in 4th grade (fifth year) of basic education of the Municipal

\footnotetext{
* Doutora em Ciência da Comunicação pela Universidade de São Paulo (ECA/ USP). Docente do Curso de Especialização em Comunicação Popular e Comunitária, Centro de Educação, Comunicação e Artes, da Universidade Estadual de Londrina (UEL), e do Curso de Jornalismo da Faculdade Maringá. Sua área de pesquisa é: mídia educação, cidadania e comunicação comunitária. Londrina-PR, Brasil. Email: adeli@sercomtel.com.br

** Mestranda em Comunicação pela Universidade Estadual de Londrina, Especialista em Comunicação Popular e Comunitária pela mesma instituição. Atua como docente no Curso de Jornalismo da Faculdade Maringá e é bolsista CAPES. Maringá-PR, Brasil. Email: flopes.mariana@gmail.com
} 
School Olavo Soares Barros in Camberley - PR. The works has aimed at reflecting on media education theory and assess the possibility of their practice to encourage the involvement of young people with its reality and thus form the development of their citizenship. The methodology consisted of literature on the assumptions of media education and also in research to understand the workshops held during the period August to December 2008. It follows that when media education is crafted in its production context aiming at awakening the children to discuss issues relating to their social surroundings, whether it be your school, your neighborhood or your city, down to an education for citizenship, set by training participation and commitment of those involved.

Key words: Media education. Citizenship. Commitment.

\section{Educación para los medios y la formación ciudadana: un análisis de las prácticas de radio de la escuela municipal Olavo Soares Barros en Cambe - PR}

\section{Resumén}

Este artículo trata de un estudio acerca de la educación en los medios basada en prácticas de la radio hecha para alunmos de cuarto grado (quinto año) de la educación básica en la escuela municipal Olavo Soares Barros en Cambe - PR. El documento se presenta teóricamente destinado a reflexionar sobre educación en los médios y evaluar la posibilidad de su práctica para fomentar el compromiso de los jóvenes con su realidad y, por lo tanto, constituyen la base para la construcción de ciudadanía. La metodología consistió en la literatura de los supuestos sobre la educación en los médios y también en la investigación-acción que incluye las prácticas realizadas durante el período de agosto a diciembre de 2008. Se deduce que, la educación en los medios, cuando trabajados em su contexto productivo tratando de despertar a los niños para discutir las cuestiones relativas a su entorno social, sea su escuela, su barrio o su ciudad, proporciona una educación para la ciudadanía compuesta por la capacitación participativa y el compromiso de los implicados.

Palabras clave: Educación en los medios. Ciudadanía. Compromiso.

\section{Introdução}

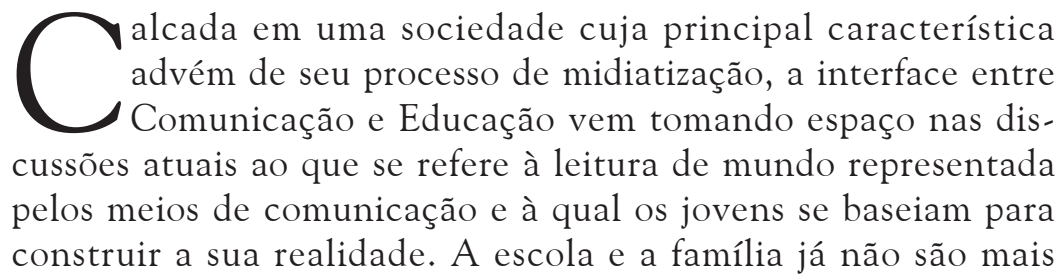




\section{MÍDIA EDUCAÇÃO E A FORMAÇÃO CIDADÃ}

as instituições que, exclusivamente, se encarregam da educação, uma vez que a mídia vem desenvolvendo esse papel. Pensar em uma educação através dos meios de comunicação, que prepare receptores críticos, conscientes e capazes de estabelecer uma relação dialógica com esses meios torna-se uma necessidade pungente na contemporaneidade.

Nesse sentido, a proposta deste trabalho é apresentar uma reflexão teórica acerca da mídia educação, focando o seu contexto produtivo em que as mídias são utilizadas como linguagem expressiva através da qual se produz uma resposta social aos meios de comunicação, bem como a formação de um sujeito comprometido com sua realidade, tendo em vista a construção de sua cidadania. Portanto, o objetivo desta pesquisa consiste em avaliar a possibilidade da mídia educação incorporar em sua prática elementos que a tornem importante práxis na promoção um sentimento de pertença e, consequentemente, incite a promoção de um sujeito atuante, crítico e comprometido com a sua realidade. Para isso, os procedimentos metodológicos empregados na pesquisa abrangem o levantamento bibliográfico acerca da mídia educação, da educação para a cidadania e do comprometimento, e a pesquisa-ação concretizada nas oficinas de rádio na Escola Municipal Olavo Soares Barros, em Cambé $\mathrm{PR}$, que ocorreram no período de agosto a dezembro de 2008. As oficinas foram ministradas aos alunos da $4^{\underline{a}}$ série (quinto ano) do ensino fundamental, no período de contraturno por duas jornalistas e então alunas ${ }^{1}$ do curso de Especialização em Comunicação Popular e Comunitária da Universidade Estadual de Londrina sob orientação da professora doutora Luzia Yamashita Deliberador.

\section{Comunicação e Educação}

A mídia educação ${ }^{2}$ emerge da interdisciplinaridade dos campos da Comunicação e da Educação, sendo que para entender a

\footnotetext{
${ }^{1}$ As jornalistas e alunas Mariana Ferreira Lopes e Nayara Carvalho Coutinho.

${ }^{2}$ Ao que se refere a interface entre Comunicação e Educação existe uma discussão terminológica. Empregam-se os termos educomunicação, comunicação educativa e mídia educação. Neste trabalho optamos por utilizar o termo mídia educação, tendo em vista que não sobrepõe um campo de conhecimento em detrimento de outro. Cf. Fantin, 2006.
} 
sua constituição, inclusive a sua finalidade, faz-se necessário uma análise da conceituação de seus campos primitivos.

Educacíon y comunicacíon son dós terminus que pueden ser entendidos de muy diversa forma; y según se los entendia, se abordará com muy diferente critério el uso de los médios em la enseñanza. Com todo el riesgo de uns simplificacíon esquemática, se puede distinguir entre dos modos de entenderlos; y la opción por uno de ellos atravesará y permeará toda la prática educativa ${ }^{3}$ (KAPLÚN, 1997, p.4).

Kaplún refere-se às duas possibilidades de definições de Comunicação e Educação como sendo a primeira as práticas de transmissão de conhecimento e a segunda as práticas dialógicas e libertadoras, ou seja, a visão de mídia educação advinda da primeira conceituação adquire um viés tecnicista reforçando a idéia dos meios de informação, enquanto a segunda apresenta por fim a geração de interlocutores e uma formação crítica através da mídia, tornando-a meios de comunicação.

A Educação pautada pela transmissão de conhecimento é apresentada como o modelo de educação bancária, no qual o educando recebe passivamente o conteúdo passado pelo educador. "Educa-se para arquivar o que se deposita. Mas o curioso é que o arquivado é o próprio homem, que perde assim seu poder de criar, se faz menos homem, é uma peça” (FREIRE, 1979, p.38). Nesse sentido, não há a formação de uma consciência crítica e o indivíduo não consegue compreender nem transformar a sua realidade. Para Freire, o papel da educação deve estar intimamente ligado às idéias de liberdade, democracia e justiça, que se constroem por uma permanente atividade crítica do homem em busca do não ajustamento a padrões, normas e ideais impostos pela sociedade. Trata-se do homem que apreende temas e tarefas de sua época, que transcende a posição de simples espectador do processo histórico e que, assim, emerge nesse processo como sujeito, um verdadeiro cidadão crítico.

\footnotetext{
3 "Educação e comunicação são dois termos que podem ser entendidos de diferentes formas; este entendimento conduzirá distintos critérios para o emprego dos meios de comunicação nos processos educativos. Apesar dos riscos de uma simplificação esquemática, pode-se distinguir dois modos de compreendê-los; e a opção por um deles determinará toda a prática educativa” (tradução livre das autoras).
} 
(...) a educação não pode contentar-se em reunir pessoas fazendo-as aderir a valores comuns forjados no passado. Deve, também, responder à questão: viver juntos, com que finalidade, para fazer o quê? E dar a cada um, ao longo de toda a vida, a capacidade de participar ativamente, num projeto de sociedade (DELORS, 1988, p.60).

A educação, nessa perspectiva, deve estimular o ímpeto criador do ser humano, combatendo a acomodação. A tarefa do educador consiste em desafiar o educando, estimulando o debate e a compreensão da realidade, propiciando uma reflexão crítica sobre a prática. $\mathrm{O}$ educando deve ser considerado como ser inacabado, característica própria de todos os seres humanos. A consciência do inacabamento leva a um movimento de busca, no qual a educação estabelece-se como processo permanente (FREIRE, 2007).

$\mathrm{O}$ significado de comunicação pode ser expresso na simples decomposição do termo comum + ação, de onde o significado "ação em comum", desde que se tenha em conta que o "algo em comum" refere-se a um mesmo objeto de consciência e não as coisas materiais, ou à propriedade de coisas materiais. A "ação" realizada não é sobre a matéria, mas sobre o outrem, justamente aquela cuja intenção é realizar o ato de duas (ou mais) consciências com objetivos comuns. Portanto, em sua acepção mais fundamental, o termo "comunicação" refere-se ao processo de compartilhar um mesmo objeto de consciência, ele exprime a relação entre consciências (MARTINO, 2001). Segundo afirma Pasquali (1973, p.10) a Comunicação deve ser entendida como uma relação biunívoca, na qual o transmissor pode ser receptor e vice versa, em um processo dialógico e participativo. Para Wolton (2006, p.15),

comunicar é ser, isto é buscar a sua identidade e sua autonomia. É também fazer, ou seja, reconhecer a importância do outro, ir ao encontro dele. Comunicar é também agir. Mas é igualmente admitir a importância do outro, portanto, aceitar nossa dependência em relação a ele e a incerteza de ser compreendido por ele.

Entretanto, a Comunicação pode tornar-se uma prática de transmissão de informação, na qual existe uma preponderância do papel do emissor em contraponto com o receptor que "diminui a 
força expansiva e autocriadora do saber, ficando reduzida a sua função popular a uma relação unilateral entre uma oligarquia informadora convertida em elite e uma multidão indiferenciada de receptores, convertida em massa" (PASQUALI, 1973, p.9). Prevalece, assim, um processo de difusão e de informação que empregam aos receptores um papel desigual em relação aos transmissores, ou como nos sugere Thompson (1998, p.35), "comparados com os indivíduos envolvidos no processo de produção e transmissão, os receptores de mensagens mediadas pouco podem fazer para determinar os tópicos ou o conteúdo da comunicação".

Assim, ao se pensar a mídia educação e sua finalidade, devese levar em conta qual o tipo de comunicação e educação que se está buscando, que nesta pesquisa é contemplada pela ideia de Gutiérrez (1978, p.25) ao afirmar que

podemos e devemos fazer de tudo o que estiver ao nosso alcance, como educadores, para transformar os meios de informação em meios de comunicação; temos que estimular e promover a perceptividade, criticismo e criatividade através desses próprios meios.

Esse entendimento de comunicação e educação vislumbra uma interface calcada em uma proposta libertadora, dialógica e de intervenção social, em detrimento do uso tecnicista dos meios de comunicação como suporte pedagógico. Assim, a mídia educação conceitua-se como

adoção de uma postura "crítica e criadora" de capacidades comunicativas, expressivas e relacionais para avaliar ética e esteticamente o que está sendo oferecido pelas mídias, para interagir significativamente com suas produções e para produzir mídias também. Neste sentido, esta discussão também envolve os direitos das crianças, pois mais que prover e/ou proteger as crianças dos meios há que se pensar em formas de prepará-las mais eficazmente para as responsabilidades do ser criança hoje. Capacitá-las a partir de suas especificidades, analisar e refletir sobre suas interações com as mídias e criar condições para a participação (na medida do possível) em decisões que dizem respeito a este contexto. $\mathrm{E}$ isso deve estar claro nas mediações escolares, visto que a educação para as mídias não se reduz aos seus meios e aos seus aspectos instrumentais, pois as mídias situam-se numa arena de produção de significados (FANTIN, 2006, p. 31).

\footnotetext{
${ }^{4}$ Grifos do autor.
} 


\section{Mídia educação, formação cidadã e comprometimento.}

O campo da mídia educação, como sustenta Fantin (2006), configura-se a partir de um escopo teórico e prático, no qual existe uma reflexão teórica sobre sua práxis, que nas palavras de Rivoltella consiste em uma "dialética entre ciência e movimento, reflexão e ativismo" (apud FANTIN, 2006, p.69)

Seu objetivo maior encontra-se no cerne de uma educação para a cidadania, ao passo que se estabelece "uma condição para a democratização de oportunidades educacionais e de acesso ao saber, o que contribui para uma redução das desigualdades sociais"(FANTIN, 2006, p.31). A cidadania pode ser entendida a partir das seguintes concepções: no campo da liberdade individual, a qual abarca a liberdade, a igualdade, a locomoção e a justiça; na participação e no exercício do poder político, por meio da participação política em todos em todos os níveis como eleições, plebiscitos, participação em órgãos de representação (sindicatos, movimentos e associações); e por fim, os direitos sociais que abrangem direito e igualdade de usufruir um modo de vida digno, por meio do acesso ao patrimônio social ligado ao consumo, ao lazer, condições e direito a leis do trabalho, à moradia, à educação, à saúde entre outros. A cidadania é um conceito que varia no tempo-espaço conforme o contexto vivido, podendo ganhar diferentes significados a partir da subjetividade de quem a exerce ou é excluído dela. Contudo, uma importante característica é que a cidadania pressupõe uma conquista popular, não se configurando como uma dádiva ou uma concessão, mas sim algo que advém da luta pelos direitos individuais, sociais e coletivos.

O campo de atuação da mídia educação não se limita às práticas inseridas na educação formal, abrangendo igualmente os âmbitos não-formais e informais ${ }^{5}$. Esse leque de possibilidades

\footnotetext{
${ }^{5}$ Segundo a definição de Gohn (2006, p.28), "A educação formal é aquela desenvolvida nas escolas, com conteúdos previamente demarcados; a informal como aquela que os indivíduos aprendem durante seu processo de socialização [...] carregadas de valores e culturas próprias, de pertencimento e de sentimentos herdados: e a educação não-formal é aquela que se aprende no "mundo da vida", via os processos de compartilhamento de experiências, principalmente em espaços de ações coletivas cotidianas”.
} 
vem delineando as práticas deste campo ao longo de seu percurso histórico. A interface entre os campos da Comunicação e Educação conta com experiências que remontam ao início do século XX, a exemplo do pedagogo francês Celéstin Freinet, que introduziu a imprensa escolar como processo pedagógico. Seu trabalho consistiu em utilizar o jornal em sala de aula, excluindo os manuais escolares. Por meio da imprensa, os alunos aprendiam gramática, matemática, além de outros conteúdos, "supondo que o conhecimento verdadeiro é sempre recriação, Freinet estimula a exploração da curiosidade, a coleta de informações - feita tanto pelos alunos como pelos professores -, o debate e, por fim, a expressão escrita"(ARANHA, 1996, p.174).

A história do debate que acompanhou as experiências envolvendo a Comunicação e a Educação foi permeada por concepções teórico-práticas assumidas ao longo do tempo. Fantin (2006) apresenta, assim, um panorama histórico desta interface que compreende as diversas fases, sendo que seu nascimento e desenvolvimento dão-se nas primeiras décadas do século 20, concomitantemente à formação da indústria cultural ${ }^{6}$. Primeiramente, há a concepção inoculatória, na qual os meios de comunicação são vistos como uma ameaça à sociedade e devem ser combatidos pela educação. Posteriormente, com os estudos semióticos inicia- se concepção da leitura crítica, que promove o discernimento e capacidade crítica voltada pra algumas mídias como o cinema. $\mathrm{O}$ contexto da ditadura, presente nos países da América Latina, fez com que os estudos e as práticas em mídia educação ganhassem uma alcunha política, de resistência ao autoritarismo. Esta concepção ideológica, aliada ao aprofundamento das análises semióticas dos

\footnotetext{
${ }^{6}$ Termo empregado pela primeira vez no livro Dialética do Esclarecimento de Adorno e Horkheimer, de 1947. Trata-se de um conceito que se refere ao processo de criação das manifestações culturais no cerne do capitalismo e a transformação da cultura em mercadoria. Adorno (1978, p.287) explica a indústria cultural como sendo um sistema no qual "em todos os seus ramos fazem-se, mais ou menos segundo um plano, produtos adaptados ao consumo das massas e que em grande medida determinam esse consumo. [...] A indústria cultural é a integração deliberada a partir do alto, de seus consumidores. Ela força a união dos domínios separados há milênios, da arte superior e da arte inferior. Com o prejuízo de ambos”.
} 


\section{MÍDIA EDUCAÇÃO E A FORMAÇÃO CIDADÃ}

meios de comunicação, das contribuições dos estudos neomarxista que colocam a mídia como um espaço de reprodução social à medida que se torna uma arena de luta hegemônica, enseja na mídia educação uma proposta de comunicação alternativa. Por fim, a autora destaca concepção das ciências sociais, a partir da interação dos estudos da semiótica, da ideologia e da análise de consumo, a mídia educação pode contribuir para a formação de um sujeito ativo.

No Brasil, assim como na América Latina, as experiências em mídia educação surgem em um contexto político peculiar: os regimes ditatoriais. As práticas de mídia educação emergem como resistência ao autoritarismo entre as décadas de 60 e 80 e se concretizam longe das escolas, em iniciativas de educação popular, promovidas pela Igreja Católica com as experiências dos Centros Populares de Cultura, Movimentos de Educação de Base e Movimentos de Cultura Popular, todos amparados no ideal da educação libertadora de Paulo Freire.

Problematizar a presença dos meios de comunicação na vida diária das comunidades, buscando uma "visão crítica", e a utilização dos dispositivos comunicacionais como recursos expressivos, dialógicos, de um conhecimento que parte do cotidiano do educando. Essas concepções foram exploradas pelos movimentos sociais, pela Igreja e pela Universidade (FONSECA, 2004, p.35).

Com o processo de redemocratização do país na década de 1980, inicia-se uma reflexão teórica acerca dessas práticas. O Ateliê da Aurora ${ }^{7}$, projeto vinculado à Universidade Federal de Santa Catarina, que disponibiliza em seu site experiências e discussões teóricas sobre a Comunicação Educação, é um dos exemplos de iniciativas pela consolidação deste campo, assim como o Núcleo de Comunicação e Educação da USP NCE/ECA/USP ${ }^{8}$.

\footnotetext{
${ }^{7}$ Site do Núcleo de Pesquisa sobre Infância, Comunicação e Artes (NICA) da Universidade Federal de Santa Catarina. Cf: http://www.aurora.ufsc.br/projeto.htm 8 Durante os anos de 1997 e 1998, um grupo de pesquisadores do NCE realizou uma pesquisa acerca da existência de um novo campo de intervenção social, confluindo a Comunicação e Educação. Foram consultados 178 especialistas de 12 países por meio de questionários, entrevistas e a realização de um workshop. Os resultados desta pesquisa podem ser conferidos em Soares (1999) e Schaun (2002).
} 
Nota-se, no Brasil, que as experiências em mídia educação ocorrem a partir de um associativismo entre ONGs, instituições de ensino e movimentos populares, acontecendo, sobretudo, em espaços não formais e informais, uma vez que não se encontra um apoio efetivo por parte dos governos para sua implementação na grade curricular de ensino. Nesse sentido, Peruzzo (2001, p.122) ao tratar dos processos educativos ensejados nos movimentos populares, por meio das práticas comunicativas, explica que

as dimensões do engajamento na dinâmica local, conteúdo das mensagens e da participação em todas as fases do processo comunicativo, em geral, acontecem interligadas e se configuram como ideal em termos de ação edu-comunicativa no âmbito dos movimentos comunitários.

A partir dessa perspectiva, a autora cunha o termo Educomunicação Comunitária para conceituar "o processo que se refere às inter-relações entre Comunicação e Educação informal (adquirida no dia-a-dia em processo não organizado) e não formal (formação estruturada e pode levar a uma certificação, mas difere da educação formal ou escolar)" (PERUZZO, 2007, p.82) À medida que os sujeitos participam do fazer midiático, inicia-se um processo de educação através da mídia, ou seja, por meio da

linguagem, forma de expressão e produção, pois assim como não se aprende a ler sem aprender a escrever, não se faz mídia educação só com leitura crítica e uso instrumental das mídias, sendo necessário aprender a escrever com as mídias (...) objetivando a interação dos sujeitos com as mídias e promovendo o conhecimento criativo e também crítico de suas linguagens (FANTIN, 2006, p.86)

Ao aliar a educação por meio da mídia com propostas que estejam embasadas na realidade dos educandos, visando não somente um processo de leitura crítica da mídia ou o processo de cognição interferido pela midiatização da sociedade, mas que estes alunos possam também fazer uso destes meios para o desenvolvimento de sua comunidade e para o fortalecimento de um sentimento de pertença, a mídia educação toma para si uma formação cidadã arraigada na reflexão crítica da realidade. Nesse sentido, a mídia educação toma partido das idéias de Paulo Freire, que invocam 


\section{MÍDIA EDUCAÇÃO E A FORMAÇÃO CIDADÃ}

para si a prática educativa a necessidade de se pensar o homem como um ser que vive no mundo e com o mundo.

Segundo Freire (1979), a vocação ontológica do homem é a de ser sujeito, desenvolvendo uma reflexão a respeito das condições espaço-temporais de sua realidade, para que ele possa, assim, introduzir-se nelas de maneira crítica. As relações que o homem vai estabelecendo com o mundo, na medida em que se afirma como ser inacabado, temporalizado e situado, são criadas e recriadas como respostas plurais aos desafios que este mundo o apresenta.

Quanto mais for levado a refletir sobre sua situcionalidade, sobre seu enraizamento espaço-temporal, mais "emergerá" dela conscientemente "carregado" de compromisso com a sua realidade, da qual, porque é sujeito, não deve ser simples espectador, mas deve intervir cada vez mais (FREIRE, 1979, p.61)

Ao entender a realidade que o cerca, o homem torna-se capaz de diagnosticar problemas, levantar hipóteses e propor soluções em relação ao seu meio, podendo assim transforma-lo. Esse comprometimento faz do sujeito um cidadão, ao passo que o

reconhecimento da sociedade por seus membros e conseqüente adesão por parte destes aos projetos comuns são duas faces da mesma moeda que ao menos como pretensão, compõem esse conceito de cidadania que constitui a razão de ser da civilidade (CORTINA, 2005, p. 20-21). ${ }^{9}$

Inserindo em sua prática a abordagem de conteúdos que estejam ligados à realidade dos jovens, as ações de mídia educação fazem emergir um sentimento de pertença à comunidade, almejando o seu desenvolvimento e concomitantemente construindo a cidadania de seus envolvidos. O comprometimento emerge na composição de sociedade atomizada ${ }^{10}$, caracterizada pela individualização do ser humano, como possibilidade de cidadania,

\footnotetext{
${ }^{9}$ Grifos do autor.

${ }^{10}$ Segundo Ilse Sherer-Warren (1993), no Brasil, a sociedade atomizada surge na complexidade da vida moderna em decorrência do êxodo rural, a escassez de tempo destinado às interações sociais, aos meios de comunicação de massa e a segregação urbana, gerando um processo de individualização crescente em que grandes ações políticas coletivas se enfraquecem.
} 
entre as diversas razões para a atualidade do termo cidadania, uma constitui o alicerce sobre qual e assentam as outras: a necessidade, nas sociedades pós-industriais, de gerar entre seus membros um tipo de identidade na qual reconheçam e que os façam sentir pertencentes a elas (CORTINA, 2005, p.16).

Surge a esperança nas coletividades onde é presente o sentimento de pertença e justiça que possibilitam a coexistência mediada pela normatização das relações de convívio, na solidariedade e identificação entre os membros de um grupo, na compreensão e respeito mútuo, ou seja, na participação a uma comunidade.

\section{A experiência das oficinas de rádio dos alunos da escola Municipal Olavo Soares Barros}

A partir das considerações acerca dos fundamentos da mídia educação e de sua prática voltada para uma formação cidadã e sua identificação com a realidade dos educandos, relataremos o trabalho realizado nas oficinas de rádio da escola Olavo Soares Barros, em Cambé - PR, no período de 11 de agosto a 08 de dezembro de 2008. Essa experiência caracteriza-se como uma pesquisa ação, a qual teve seu fundamento nas discussões levantadas no curso de especialização em Comunicação Popular e Comunitária da Universidade Estadual de Londrina.

A Escola Municipal Olavo Soares Barros está localizada no bairro Jardim José Favaro, na região periférica de Cambé. Inaugurada em agosto de 2003, a escola abrange o ensino de $1 \underline{\text { à }}$ à ${ }^{\underline{a}}$ séries do Ensino Fundamental. São cinco classes de cada série, dividas em dois turnos. No período matutino as aulas são para a $3^{\underline{a}}$ e $4^{\underline{a}}$ e no vespertino, aos alunos do $1^{\underline{a}}$ e $2^{\underline{a}}$ séries. À noite, a escola cede seu espaço para os alunos do programa de alfabetização de jovens e adultos, o EJA. Em 2008, ano em que se realizou a pesquisa, a escola atendia ao todo 557 alunos, sendo 503 do ensino regular de $1 \stackrel{a}{a}$ a $4^{a}$ séries, e 54 do EJA. O corpo docente era composto por 30 professoras, uma coordenadora pedagógica, Lourdes Zamberlan, e uma diretora, Lindomara Teodoro de Souza, além de haver os demais funcionários administrativos, como bibliotecária, zeladores e secretários. A escola é fruto da reivindicação dos moradores da 


\section{MÍDIA EDUCAÇÃO E A FORMAÇÃO CIDADÃ}

região, pois não havia uma instituição que recebesse alunos destas séries. Durante oito anos, a comunidade se uniu até que a escola fosse finalmente construída.

Os alunos participantes da pesquisa habitam os bairros Jardim José Fávaro e Jardim Ana Rosa. Segundo dados cedidos pela Secretaria Municipal de Educação, o perfil sócio-econômico do Jardim Ana Rosa é de classe baixa à média, sua população estimada é de 11 mil habitantes, divididos em cinco microregiões. Muitos de seus moradores não possuem escolaridade ou estudaram até a quarta série do ensino fundamental, sendo que poucos chegaram a concluir o ensino Fundamental e em menor número o ensino médio e superior. A maioria da população economicamente ativa trabalha como operários de indústrias, na prestação de serviços e na construção civil. O bairro sofre com problemas de infraestrutura, tais como: moradias em precárias condições; a falta de segurança pública adequada; o atendimento médico insuficiente e poucas opções de lazer.

A escolha por trabalhar nesta escola deu-se por indicação da Secretaria Municipal de Educação, uma vez que se trata de uma escola aberta a projetos extracurriculares e por já existir um sistema de caixas de som em todas as salas de aula, o que facilitaria trabalho com a mídia escolhida: o rádio. Esta escolha deve-se também às especificidades deste meio, tais como o imediatismo, a mobilidade, a penetrabilidade, a autonomia, a credibilidade, o baixo custo e a simpatia (KAPLÚN, 1978.). Além de ter sua história, no Brasil, ligada à radiodifusão educativa, sobretudo com a fundação da Comissão de Rádio Educativo, em 1933, por Roquette Pinto. A Igreja Católica também se interessou em aliar o rádio à educação por meio do Movimento de Educação de Base. "As escolas radiofônicas visavam, na época, à conscientização, mudança de atitudes e instrumentação das comunidades" (ASSUMPÇÃO, 1999, p.33).

$O$ projeto foi realizado com alunos da terceira e quarta séries ${ }^{11}$, no período de contra-turno, na biblioteca da escola. Inicialmente,

\footnotetext{
${ }^{11}$ A opção por alunos da terceira e quarta séries ao invés da primeira e segunda séries deu-se pela facilidade didática e de locomoção - uma vez que as oficinas aconteceriam no período da tarde e os alunos teriam que se deslocar novamente à escola.
} 
havia quatro turmas de 15 alunos, com aulas uma vez por semana. O projeto teve como objetivo principal utilizar a mídia como um processo educativo com vistas à promoção e desenvolvimento da cidadania, elaborando com os alunos participantes programas de rádio que abarcassem conteúdos sugeridos por eles, sensibilizandoos para um olhar crítico da mídia a partir da participação nos fazer comunicativo, contribuindo para a valorização enquanto sujeito ativo. Para isso, houve visitas à escola durante aproximadamente um mês para apresentar o projeto aos alunos e ao corpo docente, a fim de esclarecer quaisquer questionamentos, conhecer a rotina escolar e criar vínculos.

O planejamento das aulas no primeiro mês do projeto priorizou atividades que pudessem despertar nos alunos o reconhecimento deles enquanto pertencentes a uma comunidade - seja ela a escola, o bairro ou até mesmo sua cidade. Este foi um dos pontos mencionados pelas professoras quando questionadas sobre temas que as oficinas poderiam abranger. Neste período, foram trabalhados: a história de Cambé, da história da escola, quem foi Olavo Soares Barros e, também, notícias jornalísticas e acontecimentos relatados pelos alunos sobre a cidade e o bairro. A partir de uma leitura crítica da mídia, os alunos eram estimulados a refletir sobre os temas que eram considerados relevantes para serem abordados nos jornais e também, como as questões apresentadas interferiam, direta ou indiretamente, em suas vidas. Tal postura desencadeia a educação de um receptor frente às linguagens midiáticas e à sua massificação, para que se construa um sujeito atuante, "um consumidor inteligente, seletivo e crítico dos Meios de Comunicação Social" (GUTIÉRREZ, 1978, p.37).

Além disso, os alunos eram incitados a refletirem em que medida eles poderiam contribuir para solucionar, amenizar ou transformar as situações por eles reconhecidas. $\mathrm{O}$ objetivo principal destes questionamentos era desenvolver nos alunos uma consciência crítica, caracterizada pela busca de profundidade na análise dos problemas e a qual se alcança por meio de um processo educativo de conscientização (FREIRE, 1979). E, principalmente, estimular a participação em ações coletivas e sociais, uma vez que a participação em instâncias microssociais, como a comunidade e 


\section{MÍDIA EDUCAÇÃO E A FORMAÇÃO CIDADÃ}

a família é um canal para uma educação para a participação em um sentido macro (BORDENAVE, 1983, p.25). Como um dos exemplos de atividade, houve a elaboração de uma nota de uma campanha fictícia, reproduzida abaixo, após de um debate acerca do que as crianças gostavam ou não em seu bairro e o que poderiam fazer para mudar essa realidade.

Os alunos das terceiras e quarta séries da escola Municipal Olavo Soares Barros estão convidando os moradores de Cambé para um debate sobre o atendimento do Posto de Saúde do Ana Rosa. O prefeito também vai participar para conhecer a realidade do postinho. Vai ser feita uma carta com os pedidos de melhoria que será entregue ao prefeito. O debate vai acontecer no dia 15 de setembro, das 15 às 19 horas, no Redondo, As inscrições serão feitas no posto de saúde do Ana Rosa. Compareçam ao debate. Ajude a melhorar o Ana Rosa. Essa campanha faz parte da oficina de rádio da Escola Municipal Olavo Soares Barros.

As atividades subsequentes tiveram como foco principal o estudo e o reconhecimento da mídia a ser trabalhada no projeto: o rádio. Neste período, foram apresentados os vários formatos e gêneros radiofônicos, realizamos atividades de estímulo à percepção auditiva, exercícios de escuta, de recepção da mídia, além de apresentar alguns programas para que os alunos se familiarizassem com a linguagem característica do rádio. A última etapa do projeto ficou voltada à produção de um programa radiofônico a partir de temas sugeridos pelos próprios alunos. Cada programa teria duração média de 15 minutos e as turmas participaram - em diferentes graus - de todo o processo, desde a produção até a edição. Os temas dos programas foram: turma 01: a escola Olavo Soares Barros, turma 02: a importância da leitura e turma 03: a cultura negra, sendo que todos surgiram a partir de indagações e curiosidade a respeito de temos tratados em sua realidade mais próxima, no caso assuntos relacionados à escola. Para a gravação dos programas, na noite do dia 01 de dezembro de 2008, contamos com a colaboração da Rádio Universidade da UEL, que nos cedeu o estúdio, e dos jornalistas da rádio Tony Hara e Patrícia Zanin, que coordenaram as gravações. Participaram da gravação do programa, 27 dos 33 alunos da oficina, além de pais e irmãos que foram de acompanhantes. 
Os programas foram veiculados no dia 8 de dezembro, durante a festa de encerramento das aulas e todos os alunos de $3^{\underline{a}}$ e $4^{\underline{a}}$ séries, puderam escutá-los de dentro de suas salas. Durante a veiculação, tanto as professoras, quanto as crianças ficaram atentas, tentando descobrir qual aluno estava falando e interagindo com as brincadeiras. Houve muito entusiasmo e, sobretudo, orgulho do trabalho produzido. Os alunos que não participaram das oficinas, também mostraram interesse e se prontificaram a participar das próximas aulas de rádio.

Após o término das oficinas, foi realizada uma avaliação com os alunos, pais e professores. Os pais apontaram mudanças no relacionamento com os filhos, que se tornaram mais participativos e comprometidos dentro de casa, havendo mais diálogo entre os membros da família. Além de um maior interesse sobre questões da atualidade, ao assistirem telejornais, assumindo uma postura mais crítica e participativa. As professoras apontaram melhora no comportamento dos alunos na sala de aula, que se tornaram mais atuantes e questionadores. A diretora da escola salientou a importância de atividades fora da sala de aula para o desenvolvimento social dos alunos, uma vez que a educação não formal estimula a expressão e uma forma de aprendizagem diferenciada, ao trabalhar o senso crítico para além do conteúdo escolar e pelo trabalho de pesquisa realizado pelos alunos a partir de um tema lançado, o que auxiliou na construção do conhecimento sobre sua realidade. Os alunos apontaram como fatores positivos o fato das oficinas preencherem seu tempo ocioso e de ser uma forma de conhecer melhor tanto os processos e seus meios de comunicação, até de saber mais sobre a sua cidade e sua escola. Além de estimular um melhor relacionamento com outras pessoas.

\section{Considerações finais}

Objetivo deste trabalho consistiu em avaliar as possibilidades que a prática de mídia educação pode oferecer para que se forme um sujeito crítico ao que se refere ao processo comunicativo e ao seu comprometimento com a realidade envolvida. Não se tratou de apresentar uma conduta a ser seguida na práxis da interface 
entre Comunicação e Educação, mas sim, promover uma discussão acerca deste campo que vem se delineando como importante área de investigação na contemporaneidade.

Baseado na análise das oficinas realizadas com os alunos da Escola Municipal Olavo Soares Barros, observou-se que a educação através da mídia, na qual por meio da aprendizagem das linguagens midiáticas concretiza- se um processo educativo em um sentido amplo, incita a passagem de uma consciência ingênua para uma consciência crítica. Tal mudança acaba por situar esses jovens como sujeitos ativos da história, e não mais como meros objetos, ou seja, "torná-los co-participante dessa realidade em transformação". A mídia educação situa-se como processo no qual se busca uma reflexão sobre os meios de comunicação, a construção de um receptor crítico e a produção de uma resposta a esses meios, e também se apresenta como linguagem expressiva a partir da qual os alunos puderam indagar e se comprometer com a realidade na qual se inserem, visando o seu objetivo de formação cidadã. As avaliações dos pais, professores e alunos corroboram essa compreensão.

O produto final das oficinas, os programas de rádio, é exemplo disso, pois tratou de temas ligados à realidade dos educandos configurando um canal por meio do qual eles puderam ser estimulados a exercer sua cidadania e a incitar sua participação no ambiente escolar. Os alunos discutiram questões referentes à melhoria de sua escola, como na coluna "boca no trombone", na qual a partir de uma enquête realizada com outros estudantes da instituição, diagnosticaram a necessidade de haver uma quadra coberta e reivindicaram uma posição da diretoria referente a esse assunto. Também foi debatida a questão da cultura negra e sua influência nas nossas vidas, importante questionamento em uma oficina na qual havia uma predominância de negros. A turma que se dedicou à importância da leitura assumiu uma postura de mostrar para os outros alunos que a biblioteca da escola era um patrimônio dos educandos e deveria por todos ser cuidada.

Ao aliar um trabalho de leitura crítica da mídia, formação de receptores críticos, produção de resposta aos meios de comunicação e assuntos que estejam diretamente ligados à realidade dos jovens, a mídia educação incitou um comprometimento que 
faz desses alunos sujeitos participantes e conscientes de seu papel em sua comunidade e, assim, exercem sua civilidade. $\mathrm{O}$ espaço para essa atuação situou-se predominantemente em iniciativas na educação não-formal, cujo desvinculo com os conteúdos aplicados na sala de aula e a ênfase em aspectos subjetivos, possibilitou uma aprendizagem diferenciada.

\section{REFERÊNCIAS}

ADORNO, Theodor. W. A indústria Cultural. In: COHN, Gabriel. Comunicação e indústria cultural. São Paulo: Companhia Editora Nacional, 1971.

ARANHA, Maria Lucia de Arruda. História da educação. São Paulo: Moderna, 1996.

ASSUMPÇÃO, Zeneida Alves de. Radioescola: uma proposta para o ensino de primeiro grau. São Paulo: Annablume, 1999.

BORDENAVE, Juan Díaz. O que é participação. São Paulo: Cortez, 1983.

CORTINA, Adela. Cidadão do Mundo: para uma Teoria da Cidadania. São Paulo: Loyola, 2005.

DELORS, J. Educação: um tesouro a descobrir. São Paulo: Cortez-UNESCOMEC, 1988.

FANTIN, Mônica. Mídia-educação: conceitos, experiências, diálogos BrasilItália. Florianópolis: Cidade Futura, 2006.

FONSECA, Cláudia Chaves. Os meios de comunicação vão à escola?. Belo Horizonte: Autêntica.2004.

FREIRE, Paulo. Educação e mudança. 15. ed. Rio de Janeiro: Paz e Terra, 1979.

. Pedagogia da Autonomia - saberes necessários à prática educativa. Rio de Janeiro: Paz e Terra, 2007.

GOHN. Maria da Glória. Educação não-formal, participação da sociedade civil e estruturas colegiadas nas escolas. In: Ensaio: avaliação pol.publ.Educacionais. Rio de Janeiro, v.14, n.50, p.27-38, jan/mar. 2006 


\section{MÍDIA EDUCAÇÃO E A FORMAÇÃO CIDADÃ}

GUTIÉRREZ, Francisco. Linguagem Total. Uma Pedagogia dos Meios de Comunicação. São Paulo: Sumus, 1978.

KAPLÚN, M. Producción de programas de radio. Quito: CIESPAL, 1978. . De médios y fines em comunicación educativa. In: Chasqui, R.L.C (58) - Junho de 1997, Quito: CIESPAL.

LOPES, Mariana Ferreira. Mídia Educação e formação cidadã: a oficina de rádio da Escola Municipal Olavo Soares Barros. Londrina: Universidade Estadual de Londrina, 2009. 125p. Monografia (Especialização em Comunicação Popular e Comunitária) - Universidade Estadual de Londrina, Londrina, 2009.

MARTINO, Luiz C.De qual comunicação estamos falando? P. 11-26. IN: HOHLFELD, Antonio, Luiz C. Martino, Vera Veiga França (orgs). Teorias da comunicação: conceitos, escolas e tendências. Petrópolis: Vozes, 2001.

PASQUALI: Antonio. Sociologia e comunicação. Petrópolis: Editora Vozes, 1973.

PERUZZO, Cicília M. K. Comunicação comunitária e educação para a cidadania. PCLA: Revista Pensamento Comunicacional Latino-Americano. São Bernardo do Campo: UMESP/Cátedra Unesco, n.1 out/nov/dez.2002.

. Rádio Comunitária, Educomunicação e Desenvolvimento. In: PAIVA, Raquel. (org). O retorno da comunidade: os novos caminhos do social. Rio de Janeiro: Mauad, 2007. p. 69 - 92.

SCHAUN, Ângela. Educomunicação: reflexões e princípios. Rio de Janeiro: Mauad, 2002.

SCHERER-WARREN. Redes de movimentos sociais. São Paulo: Oriola, 1993.

SOARES, Ismar. A emergência de um novo campo e o perfil de seus profissionais. Contato: Revista Brasileira de Comunicação, Arte e Educação. Brasília: Senado Federal, a.1, n. 2, p. 19-74. jan./mar. 1999.

THOMPSON, J.B. Mídia e modernidade: uma teoria social da mídia. Petrópolis: Vozes, 2002.

WOLTON, Dominique. É preciso salvar a comunicação. São Paulo: Paulus, 2006.

Recebido em: 02.09.2010

Aceito em: 30.01.2011 